Kapata Arkeologi, 12(1), 29-42

ISSN (cetak): 1858-4101

ISSN (elektronik): 2503-0876

http://kapata-arkeologi.kemdikbud.go.id

\title{
PERANGKAT SISTEM INFORMASI GEOGRAFIS (SIG) DALAM PENELITIAN DAN PENYAJIAN INFORMASI ARKEOLOGI
}

\section{Geographic Information System (GIS) in Research and Presentation of Information Archaeology}

\author{
Muhammad Al Mujabuddawat \\ Balai Arkeologi Maluku - Indonesia \\ Jl. Namalatu-Latuhalat Ambon 97118 \\ mujab@kemdikbud.go.id
}

Naskah diterima: 17/09/2016; direvisi: 14/11 - 30/11/2016; disetujui: 30/11/2016

Publikasi ejurnal: 30/12/2016

\begin{abstract}
Archaeology is closely associated with spatial or spatial aspects. Because the material archeological data such as artifacts, features, buildings, and sites containing the inherent spatial information in order to keep the data context. The themes of the archaeological research nowadays often reconstructing the spatial aspects of history and culture. Device Geographic Information System (GIS) is clearly greatly assist the process of archaeological research both in the field and during the process of analysis and presentation of information related to the results of the research. GIS has become the main choice for researchers to update the development of archeology that have been all-digital, practical, and effective. Although the use of GIS in archaeological research is very popular in many countries, in fact the use of GIS in archaeological research in Indonesia is still not that popular. This paper presents the use of GIS tools that allowed to be applied by archaeologists that can be adopted in the analysis and presentation of information and research results, conditions of application of GIS in the current archaeological research, as well as the constraints faced. This paper shows that recently the archaeologists in Indonesia is very enthusiactic in using the GIS for the effective spatial analysis tools. The government is also concerned about the importance of GIS in mapping the spatial data of heritage as well archaeological research locations in order to support the acceleration of One Map Policy.
\end{abstract}

Keywords: Geographic Information System (GIS), geospatial, researcher, archeology, One Map Policy

\begin{abstract}
Abstrak
Ilmu arkeologi sangat erat kaitannya dengan aspek keruangan atau spasial. Karena materi data arkeologi seperti artefak, fitur, bangunan, dan situs mengandung informasi spasial yang melekat agar tidak kehilangan data konteksnya. Tema-tema penelitian arkeologi dewasa ini tidak sedikit yang bertemakan aspek spasial dalam merekonstruksi sejarah dan budaya. Perangkat Sistem Informasi Geografis (SIG) jelas sangat membantu proses penelitian arkeologi baik di lapangan maupun saat proses analisis dan penyajian informasi terkait hasil penelitian semacam itu. SIG menjadi pilihan bagi peneliti arkeologi dalam mengikuti perkembangan dunia riset yang serba digital, praktis, dan efektif. Walaupun penggunaan perangkat SIG dalam penelitian arkeologi sangat populer di banyak negara, namun kenyataannya penggunaan perangkat SIG dalam penelitian arkeologi di Indonesia belum cukup polpuler. Penelitian ini menyajikan penggunaan perangkat SIG yang memungkinkan diterapkan oleh peneliti arkeologi yang dapat membantu dalam proses analisis dan penyajian informasi hasil penelitian, kondisi penerapan perangkat SIG di dalam penelitian arkeologi saat ini, serta kendala-kendala yang dihadapi. Penelitian ini menunjukkan bahwa dewasa ini perhatian peneliti arkeologi di Indonesia terhadap peran SIG cukup terbuka mengingat kebutuhan perangkat analisis spasial yang efektif. Pemerintah juga menaruh perhatian akan pentingnya SIG dalam memetakan data spasial Cagar Budaya dan Lokasi penelitian arkeologi dalam rangka mendukung percepatan kebijakan One Map Policy atau kebijakan Satu Peta.
\end{abstract}

Kata kunci: Sistem Informasi Geografis (SIG), geospasial, peneliti, arkeologi, Kebijakan Satu Peta 


\section{PENDAHULUAN}

Arkeologi ialah ilmu yang mempelajari tentang budaya masa lampau lewat tinggalan materinya (Greene, 2003: 130). Karena telah melewati proses berjalannya waktu, material tinggalan arkeologi biasanya terbatas (Simanjuntak, 1999: 8) berbentuk fragmentaris, antara lain artefak, ekofak, dan fitur. Data arkeologi merupakan cerminan tingkah laku masa lampau yang telah bias (Schiffer, 1976: 11). Peran arkeologilah yang merekonstruksi dan mengungkap budaya dari tinggalantinggalan tersebut. Tinggalan-tinggalan arkeologis biasanya ditemukan di atas permukaan tanah maupun di dalam tanah. Dalam proses perjalanannya, penelitian arkeologi sangat berkaitan dengan kerja turun lapangan. Perkembangan yang muncul berkaitan dengan metode penelitian lapangan telah dilakukan dalam penelitian survey dan ekskavasi (Bronson, 1978 dalam Simanjuntak, 1999: 11). Penelitian arkeologi dilakukan di lokasi ditemukannya tinggalan-tinggalan arkeologis, tinggalantinggalan arkeologis merupakan data lapangan dalam penelitian arkeologi. Lokasi ditemukannya tinggalan-tinggalan arkeologis didapat oleh Peneliti arkeologi dari berita masyarakat, literatur, sumber sejarah, maupun survey langsung di lokasi yang diperkirakan ditemukannya tinggalan arkeologis (Suantika, 2012: 188). Lokasi yang mengandung tinggalan arkeologis disebut Situs (Sharer \& Ashmore, 1979: 72). Penamaan situs-situs arkeologi biasanya merupakan nama daerah, nama lokal, maupun penamaan oleh peneliti.

Pada proses berikutnya, dalam proses analisis data arkeologi, pemetaan lokasi dalam wujud peta dan penggunaan Sistem Informasi Geografis (SIG) menjadi sangat penting karena sangat berkaitan erat dengan analisis konteks spasial data tersebut (Shaw \& Jameson, 1999: 538). Istilah pemetaan dalam hal ini ialah suatu proses dalam pembuatan atau penyusunan data dalam bentuk peta. Peta ialah gambaran permukaan bumi maupun di bawah permukaan bumi yang digambarkan dalam bidang datar dengan skala tertentu (Kresnawati \& Atmadilaga, 2004: 1). Pada perkembangannya penyajian peta tidak sebatas pada informasi geografi bumi, namun juga dipadukan dengan informasi-informasi tematis. Kemampuain SIG dibutuhkan untuk memproses data keruangan yang ada pada sebuah situs Cagar Budaya untuk kemudian menghasilkan data keruangan baru dalam bentuk peta tematik (statistik visual) yang dapat dijadikan dasar dalam penentuan tindakan dan atau kebijakan pelestarian yang bisa dilakukan bagi situs Cagar Budaya tersebut (Sujana, 2015: 58-59). Peta juga menjadi hasil laporan penelitian sebagai bentuk rekam jejak penelitian arkeologi di suatu lokasi situs. Informasi yang tersaji dalam peta hasil penelitian arkeologi dapat menjadi bahan acuan bagi pemangku kebijakan untuk mengambil kebijakan-kebijakan terkait pengembangan situs dan pembangunan daerah.

Sejarah penggunaan peta dalam arkeologi sudah muncul sejak awal abad ke-20 di Eropa. Pada awal abad ke-20 di Jerman, penelitian arkeologi cenderung menekankan perhatian terhadap kesimpulan dari sebaran benda dan situs arkeologi dalam satuan-satuan ruang, lalu mengembangkan pembuatan peta-peta sebaran artefak untuk melihat perbedaan-perbedaan serta menerangkan kompleks-kompleks budaya. Namun cara analisis pada masa itu umumnya bersifat intuitif (Clarke, 1977: 2). Pada perkembangan selanjutnya Cyril Fox mengembangkan teknik pemaduan sebaran benda atau situs arkeologi dengan peta sebaran sumber daya alam dalam suatu wilayah luas yang mengalami perubahan-perubahan dalam kurun waktu beberapa ribu tahun (Fox, 1922; 1932 dalam Mundarjito, 1993: 7). Perkembangan hingga saat ini, SIG disadari sangat penting bagi kalangan arkeolog dan menjadi bagian dari tendensi disiplin arkeologi, memenuhi relung penting dalam alat metodologi seorang arkeolog (Wheatley \& Gillings, 2002: 20). Walaupun penggunaan SIG mewakili alat metodologi penting dalam mengkaji sebaran benda dalam konteks spasial, namun penting diingat bahwa SIG tidak mewakili pendekatan teoritis dalam disiplin arkeologi. Sesuai dengan pendapat Claxton (1995) serta berdasarkan pada pengamatan Hodder (1999), bahwa GIS hanya digunakan sebagai alat bantu untuk analisis arkeologi (Robertson, Seibert, Fernandez, \& Zender, 2006: xix).

Pada masa kini, hampir setiap lembaga baik pemerintah maupun swasta memiliki peta yang disusun untuk menyajikan informasi tematis menyangkut kebijakan maupun tematema tertentu. Peta dirasa dapat menyajikan data yang informatif dan mudah dipahami oleh khalayak umum. Tampilan layout peta dibuat 
menarik namun tetap informatif menyajikan data. Karena itu, penyajian data dalam bentuk peta menjadi sangat populer di masa kini. Dalam bidang arkeologi, data pemetaan menjadi bahan analisis yang sangat membantu dalam merekonstruksi konteks keruangan (Mundarjito, 1993: 37). Peta juga tentunya dapat menjadi bentuk penyajian informasi dalam publikasi hasil penelitian kepada masyarakat. Sajian peta juga menjadi sangat penting bagi peneliti dalam penulisan laporan penelitian dan artikel ilmiah. Tanpa adanya peta, informasi keletakan suatu situs dirasa kurang lengkap dan belakangan ini menjadi perhatian di kalangan peneliti di berbagai bidang yang sependapat bahwa peta adalah bagian dari alat metodologi penelitian ilmiah.

Sejauh ini, penyajian peta tematis hasil penelitian arkeologi belum banyak ditemukan di Indonesia. Dapat diketahui dari sistem pencarian google apabila memasukkan kata kunci menyangkut situs arkeologi, penelitian arkeologi, atau artikel arkeologi. Beberapa hasil yang didapat adalah peta-peta umum yang bersumber dari google. Publikasi peta-peta tematis yang bersifat informatif dari Lembaga riset arkeologi yang berada di bawah Puslit Arkenas, Balitbang Kemdikbud tidak sebanyak peta-peta dari berbagai instansi lainnya, sebagaimana dapat dilihat contohnya dari instansi BNPB yang menginformasikan segala bentuk resiko dan penanggulangan bencana daerah dalam bentuk peta dengan berbagai tema yang disajikan dalam ratusan lembar peta beragam tema. Bentuk publikasi informasi dalam bentuk peta di Lembaga riset arkeologi dirasa masih kalah dari lembaga yang ada kaitannya di bidang arkeologi namun tidak menyangkut riset, yaitu BPCB. BPCB (Balai Pelestarian Cagar Budaya) adalah lembaga pemerintah yang bergerak di bidang pelestarian cagar budaya di bawah Ditjen Kebudayaan Kemdikbud. BPCB sebagai lembaga pelestarian dan pengembangan memang memiliki tugas pokok dan fungsi yang lebih dekat ke publik dibandingkan Balai Arkeologi yang hanya fokus di penelitian. Karena itulah dalam menjalankan tugas pokok dan fungsinya BPCB memang lebih familiar dengan konsep pemetaan yang hasilnya untuk publikasi dan acuan penentu arah kebijakan. Berdasarkan tugas pokok dan fungsinya, BPCB memang harus memiliki tenaga ahli di beragam bidang, termasuk tenaga ahli di bidang pemetaan. Pemetaan yang dilakukan oleh BPCB berupa tema pemetaan letak lokasi situs, delineasi situs, dan pengembangan situs. Memang dalam perjalanan dua lembaga ini terjadi perdebatan yang biasanya para peneliti di Lembaga riset Balai Arkeologi cenderung beranggapan penyajian peta tematis mengenai arkeologi merupakan bagian dari BPCB, namun perlu diingat bahwa sejatinya BPCB merupakan lembaga yang memperoleh referensi terkait arkeologi dan informasi budaya lainnya dari Lembaga riset yang menelitinya terlebih dahulu, yaitu Balai Arkeologi. Sehingga tentunya informasi atau tema pemetaan yang disajikan seharusnya berbeda kebutuhannya antara tema yang berkaitan tentang riset dengan informasi publik yang cenderung bertemakan informasi yang lebih kompleks dan lebih mudah dipahami oleh pemangku kebijakan dan khalayak umum.

Mengingat pentingnya pemetaan di bidang arkeologi, Pusat Penelitian Arkeologi Nasional (Puslit Arkenas) membentuk Sistem Pemetaan Arkeologi Nasional yang disebut SPAN. SPAN dibentuk sejak tahun 2010, kegiatan awalnya ialah mengadakan pelatihan tenaga pemetaan dari 10 Balai Arkeologi se Indonesia yang dilakukan setiap tahun, hingga beberapa waktu belakangan SPAN diarahkan untuk membantu program Kebijakan Presiden One Map Policy atau Kebijakan Satu Peta. One Map Policy merupakan program pemerintah yang merupakan salah satu program utama yang diinstruksikan langsung oleh Presiden berdasarkan amanat Undang-undang No. 4 tahun 2011 tentang Informasi Geospasial (Indonesia, 2011). Dalam menjalankannya, dibawahi oleh Menteri Koordinator Perekonomian untuk menyusun satu peta yang memuat berbagai informasi dari seluruh Kementerian dan Lembaga pemerintah termasuk informasi geospasial situs Cagar Budaya dan Lokasi Penelitian Kemdikbud yang membawahi instansi Balai Arkeologi dan BPCB. Tujuan program One Map Policy ini secara umum ialah untuk menghindari konflik spasial dalam pengambilan kebijakan, serta dalam rangka efisiensi pemerintah dalam menjalankan program pembangunan (Indonesia, 2016). Sejauh ini, dalam rangka mendukung program One Map Policy, Puslit Arkenas melalui SPAN menginstruksikan kepada seluruh Balai Arkeologi sebatas mengumpulkan data 
informasi atribut Situs yang mencakup koordinat geografis dan informasi umum Situs.

Dapat kita lihat betapa pemerintah sangat memperhatikan pentingnya informasi peta yang diwujudkan dalam program One Map Policy, maka Lembaga riset arkeologi dirasa perlu memiliki pandangan serupa. Tidak perlu diperdebatkan lagi bahwa pemetaan dalam penelitian arkeologi merupakan hal yang penting dalam analisis dan penyajian data. Peneliti arkeologi sudah saatnya meninggalkan sekadar gambaran deskriptif tentang lokasi situs atau analisis spasial tanpa menyajikan peta, atau menyajikan peta yang bersumber dari google atau referensi lain yang tentunya memiliki tema yang berbeda dari yang dibutuhkan. Dalam penelitian arkeologi, sudah menjadi barang wajib bahwa data pemetaan menjadi sumber akurat untuk analisis dan penyajian data hasil penelitian. Saat ini pemetaan dirasa sudah cukup maju mengingat banyaknya software yang membantu dalam pembuatan peta, analisis data spasial, serta lembaga-lembaga yang menyajikan database geospasial. Software yang paling populer yang banyak digunakan oleh Peneliti, akademisi, maupum khalayak umum di Indonesia antara lain Mapsource Garmin, ArcGis, QGis, dan Global Mapper. Softwaresoftware tersebut memiliki keunggulan masingmasing dalam pembuatan peta, sehingga dalam prosesnya bisa memadukan beberapa software dalam mengolah data pemetaan. Software dan database geospasial yang digunakan dalam mengolah data pemetaan dalam hal ini dikenal dengan Sistem Informasi Geografis (SIG), maka dalam tulisan ini mengulas jawaban dari pokokpokok bahasan berikut,

1. Fungsi dan penerapan SIG dalam penelitian Arkeologi

2. Bentuk-bentuk penyajian data SIG dalam Arkeologi

3. Apa saja kendala-kendala dalam proses SIG

4. Masa depan SIG dalam Penelitian arkeologi

\section{METODE}

Berdasarkan kerangka yang telah dijabarkan, maka metode yang digunakan dalam tulisan ini ialah pendekatan kualitatif melalui observasi, studi pustaka, dan aplikasi software. Observasi dilakukan dengan cara pengamatan terhadap sejumlah fenomena mengenai isu-isu penelitian arkeologi yang berkaitan dengan pendekatan geospasial di Lembaga riset arkeologi. Studi pustaka dilakukan dengan cara mencari referensi terkait dengan Sistem Informasi Geografis, serta bentuk-bentuk penggunaan dan penyajian data geografis dalam kaitannya dengan penelitian arkeologi. Setelah memperoleh data yang cukup dari hasil observasi dan studi pustaka, maka dilanjutkan dengan analisis di aplikasi software yang memungkinkan untuk diterapkan di Lembaga riset arkeologi guna menganalisis dan menyajikan data geospasial. Seluruh rangkaian proses metode tersebut disajikan dalam bentuk kajian di dalam tulisan ini.

\section{HASIL DAN PEMBAHASAN \\ Fungsi dan Penerapan SIG dalam Penelitian Arkeologi}

Sistem Informasi Geografis (SIG) ialah sistem informasi berbasis komputer yang digunakan untuk mengolah dan menyimpan data atau informasi geografis (Aronoff, 1989 dalam Munajati, Anadra, \& Aprianto, 2010: 70). Secara umum SIG merupakan suatu komponen yang terdiri dari perangkat keras, perangkat lunak, data geografis, dan sumber daya manusia yang bekerja bersama secara efektif untuk memasukan, menyimpan, memperbaiki, memperbaharui, mengelola, memanipulasi, mengintegrasikan, menganalisa, dan menampilkan data dalam suatu informasi berbasis geografis (Johnson, 1996 dalam Yuwono, 2007: 108). SIG mempunyai kemampuan untuk menghubungkan berbagai data pada suatu titik tertentu di Bumi, menggabungkannya, menganalisa, dan akhirnya memetakan hasilnya. Data yang akan diolah pada SIG merupakan data spasial, yaitu sebuah data yang berorientasi geografis dan merupakan lokasi yang memiliki sistem koordinat tertentu, sebagai dasr referensinya. Sehingga aplikasi SIG dapat menjawab beberapa pertanyaan seperti lokasi, kondisi, trend, dan pemodelan. Kemampuan inilah yang membedakan SIG dari sistem informasi lainnya.

Pada bidang arkeologi, SIG mulai dikembangkan sejak diadakannya pertemuan ilmiah Society for American Archaeology di Amerika pada tahun 1985 yang bertemakan "Sistem Informasi Geografis (SIG) berbasis komputer: alat masa depan untuk memecahkan problema masa lalu" (Harris \& Lock 1990 dalam Yuwono, 2007: 115). Perannya di bidang 
arkeologi semula adalah dalam konteks Pengelolaan Sumberdaya Arkeologi yang banyak menerapkan analisis lokasional. Dalam aplikasi ini, SIG banyak memberikan masukan dalam proses pengambilan keputusan. Model prediksi yang dibangun memungkinkannya untuk diaplikasikan sebagai perangkat klasifikasi, kalkulasi, kombinasi, dan visualisasi kenampakan variabel-variabel spasial. Dengan berbagai kelebihan tersebut sangatlah beralasan untuk menjadikan SIG sebagai perangkat manajemen data utama dalam kegiatan Pengelolaan Sumberdaya Arkeologi (Judge \& Sebastian 1988 dalam Yuwono, 2007: 115). Penggunaan SIG dalam penelitian arkeologi disesuaikan berdasarkan tujuan dan tema penelitiannya. Belakangan ini, aplikasi SIG dan penelitian arkeologi biasanya diterapkan dalam kajian arkeologi lansekap. Arkeologi lansekap mengandung pengertian sebagai cabang arkeologi yang menekankan kajian dan pendekatannya pada hubungan antara corak dan sebaran fenomena arkeologis dengan karakterisik perubahan bentang lahan/fisiografi sekitarnya (Yuwono, 2007: 121).

Pendekatan arkeologi lansekap membutuhkan analisis spasial karena menjelaskan hubungan antara sebaran fenomena arkeologi dan konteks geografis. Sehingga kajian arkeologi lansekap memerlukan ketersediaan bentuk-bentuk representasi spasial (peta, foto udara, citra satelit), baik dalam kedudukannya sebagai data, instrumen analisis, maupun hasil kajian. Karena suatu lansekap dibentuk oleh beberapa komponen, terutama bentuk lahan, tanah, air, vegetasi, dan berbagai bentuk pengaruh manusia, maka diperlukan peta dasar dan berbagai peta tematik, termasuk struktur basis datanya agar dapat dilakukan analisis spasial (Yuwono, 2007: 122). Wuri Handoko membuat beberapa model kerangka metodologi arkeologi lansekap dalam kajian situs-situs negeri lama. Dari beberapa model tersebut, salah satunya ialah pengamatan lansekap untuk melihat korelasi antar situs, apakah keletakan situs-situs itu terdapat dalam satu gugusan atau rangkaian bukit yang sama tanpa terpisah atau tanpa batas-batas oleh lembah, sungai, dan sebagainya. Kajian ini berguna untuk interpretasi konsep hubungan baik sosial maupun ekonomis antar situs (Handoko, 2008: 97).

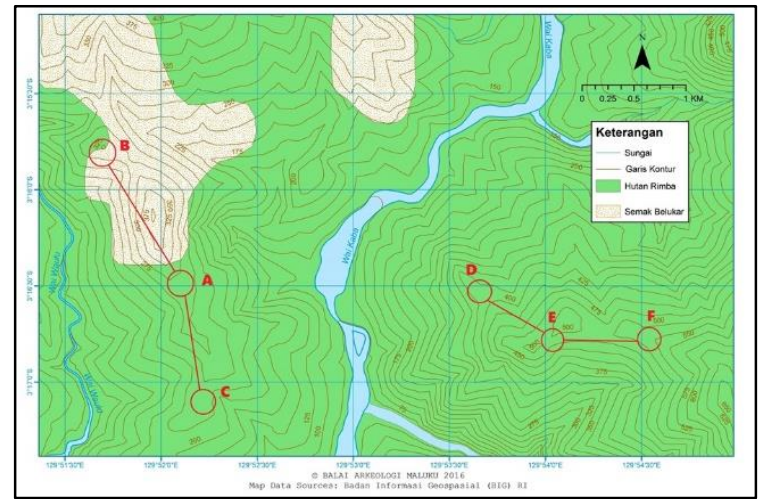

Gambar 1. Ilustrasi hubungan sosial ekonomi situssitus Negeri Lama berdasarkan lansekap

(Sumber: Peta dasar BIG dimodifikasi oleh penulis dengan ArcGis)

Situs negeri lama yang tak terpisahkan oleh batas-batas lembah atau lansekap lainnya memudahkan untuk saling berhubungan (Handoko, 2008: 98). Seperti tampak pada ilustrasi pada gambar 1 yang mengiterpretasikan antara situs negeri lama A, B, dan C lebih mudah untuk saling berhubungan karena terletak pada satu lansekap bukit sehingga hubungan sosial ekonomi mudah terjalin, sedangkan hubungan antara situs negeri lama A dengan situs negeri lama D dibatasi oleh lansekap lembahan sungai, sehingga kemungkinan hubungan sosial ekonomi lebih jarang terjadi. Selain pengamatan yang teliti terhadap lingkungan situs, juga dibutuhkan ketelitian dalam mencocokkannya dengan peta topografi kawasan. Pengamatan terhadap perbedaan luas areal datar dan tinggi letak situs, tujuannya adalah untuk mengkaji apakah berhubungan dengan skala situs dan masyarakat penghuninya atau hanya faktor kemampuan adaptasi manusia terhadap lingkungan (Handoko, 2008: 98). Pemanfaatan SIG dan penginderaan jauh dalam bidang arkeologis terbukti sangat mampu dan efisien dalam memberikan informasi spatial landscape yang lebih komprehensif. SIG juga dapat digunakan sebagai instrumen untuk mengintegrasikan fakta dan analisa lain dalam referensi spasial (Habib \& Poniman, 2010: 112).

Sebagai suatu sistem informasi, pengoperasian SIG memerlukan sejumlah komponen, antara lain data spasial, software, dan hardware. Data spasial ialah data yang berorientasi geografis yang berisi data lokasi dan data atribut. Data lokasi berkaitan dengan suatu informasi koordinat geografi, sedangkan data atribut ialah data informasi deskriptif tentang 
suatu lokasi, seperti jenis vegetasi, populasi, luasan, dan sebagainya. Software yang populer digunakan dalam menjalankan SIG ialah ArcView dan ArcGis dari ESRI, Qgis, Mapsource, dan Global Mapper. Softwaresoftware tersebut memiliki kelebihan masingmasing, jadi dalam pengoperasian SIG, dapat menggunakan gabungan beberapa software dalam membantu analisis penelitian arkeologi. Hardware berupa seperangkat komputer yang mendukung pengoperasian software. Dalam menjalankan software SIG setidaknya membutuhkan seperangkat komputer atau laptop yang memiliki RAM 4 GB agar dapat menjalankan software dengan performa yang baik. Untuk menghasilkan data analisis arkeologi dengan menggunakan aplikasi SIG, maka memerlukan serangkaian tahap yang harus dilakukan. Tahap-tahap tersebut mengikuti rangkaian proses penelitian yang berlangsung mulai dari saat observasi di lapangan, tahap analisis, hingga penyajian hasil analisis.

\section{Praktek SIG di Lapangan}

Persiapan yang dilakukan sebelum Peneliti dan tim turun ke lapangan salah satunya ialah orientasi medan. Orientasi medan dalam hal ini ialah mengumpulkan informasi mengenai kondisi fisik di lingkungan sekitar situs. Informasi mengenai medan/kondisi lapangan ini diantaranya dapat diperoleh dari peta topografi dan informasi yang ditampilkan dari visualisasi database SIG. Peta topografi atau peta Rupa Bumi Indonesia (RBI) dicetak oleh Ditjen Topografi TNI AD dan Badan Informasi Geospasial (BIG). Badan Informasi Geospasial adalah Lembaga Pemerintah Non-Kementerian yang lahir berdasarkan Undang-Undang No. 4 Tahun 2011 yang mempunyai tugas melaksanakan tugas-tugas pemerintahan di bidang informasi geospasial (Hakim, Riqqi, \& Harto, 2014: 37). Peta topografi dan peta RBI yang dibuat oleh BIG dan dapat diperoleh biasanya dalam ukuran skala 1:25.000 1:250.000. Namun tidak seluruh bagian peta Indonesia memiliki skala 1:25.000, peta RBI untuk blat luar Jawa sebagian besar berukuran skala 1:50.000 - 1:250.000. Lembar peta RBI dapat diperoleh dengan cara membelinya langsung di Kantor BIG, Bogor atau instansiinstansi yang ditunjuk BIG untuk menjual peta RBI. Sedangkan Ditjen topografi TNI AD mengeluarkan lembar peta berskala 1:50.000 -
1:100.000. Lembar peta yang diterbitkan oleh TNI AD dapat diperoleh dengan cara menyurat resmi ke kantor TNI AD di berbagai wilayah di Indonesia.

Lembar peta lokasi penelitian dijadikan acuan dalam riset medan. Peneliti terlebih dahulu melihat kondisi geografis lokasi penelitian yang dituju berdasarkan referensi peta. Peneliti dapat menyiapkan target waktu, lokasi, transportasi, persiapan logistik, perlengkapan, dan berbagai anggaran lainnya dengan orientasi medan yang berdasar pada peta. Namun dengan adanya SIG, maka orientasi medan menjadi lebih mudah. Software yang biasa digunakan ialah ArcGis. ArcGis ini memiliki perangkat-perangkat lain di dalamnya, antara lain ArcMap, ArcGlobe, dan ArcCatalog. Untuk menampilkan database peta, maka dengan membuka ArcMap. Dengan membuka software ini, maka proses riset medan pra penelitian dengan jangkauan lebih luas dengan berbagai kemudahan dari fitur yang tersedia.

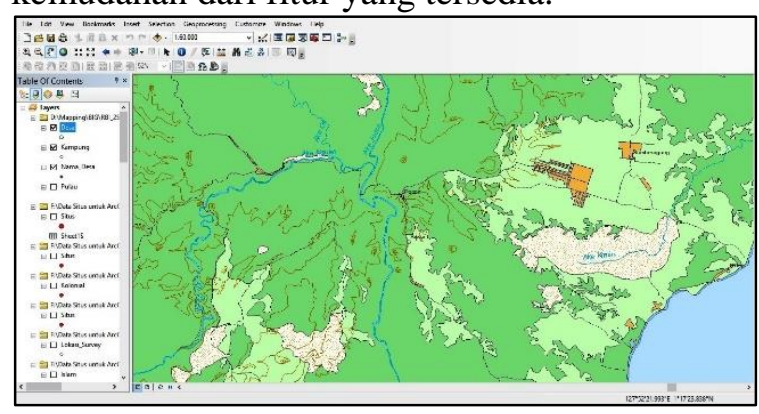

Gambar 2. Tampilan dataset ArcMap

(Sumber: Peta dasar BIG diolah dalam ArcGis-

ArcMap, 2016)

ArcMap dapat menampilkan dan menghilangkan data spasial yang diinginkan. Data spasial yang dapat ditampilkan antara lain, data geografis batas wilayah, toponimi, hipsografi, hidrografi, vegetasi, utilitas, transportasi, lingkungan terbangun, referensi spasial, hingga data penggunaan lahan. Data yang ingin ditampilkan dapat disesuaikan berdasarkan kebutuhannya, apabila membutuhkan referensi untuk akomodasi, waktu tempuh, dan rute menuju lokasi penelitian atau situs, maka tampilkan data transportasi yang berisi sarana jaringan jalan raya, jalur kereta, jalan setapak, dan lain-lain. Apabila ingin mendapatkan referensi tentang lokasi penelitian/situs, maka biasanya peneliti membutuhkan data vegetasi, permukiman, penggunaan lahan, garis kontur, dan sungai. 
Setelah menampilkan data spasial yang dibutuhkan, lalu peneliti bisa melanjutkan riset dan perencanaan dengan membuat rute dan ploting lokasi yang akan dituju untuk survey/observasi lapangan.

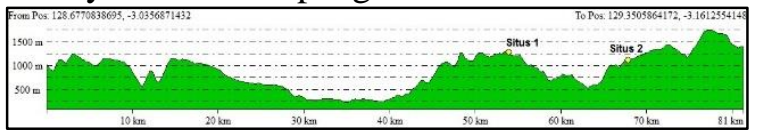

Gambar 3. Contoh tampilan penampang melintang rute perjalanan $1: 2$

(Sumber: Data SRTM Worlwide Elevation, diolah dalam Global Mapper, 2016)

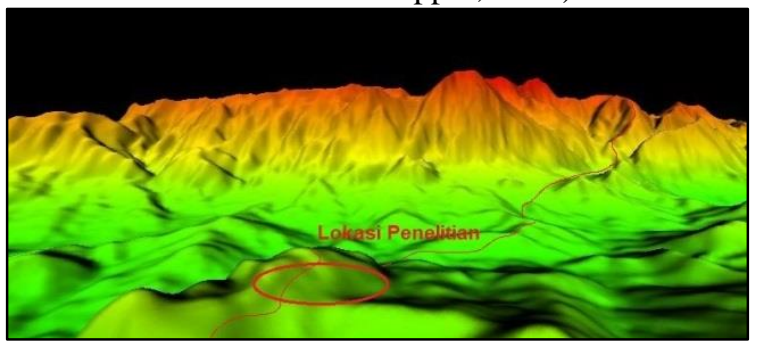

Gambar 4. Contoh tampilan 3D lansekap lokasi penelitian

(Sumber: Data SRTM Worlwide Elevation, diolah dalam Global Mapper, 2016)

Pembuatan rute mungkin dibutuhkan apabila lokasi yang dituju berada cukup jauh dari permukiman dan diperlukan proses tempuh dengan berjalan kaki, maka penyiapan rencana rute tracking menjadi sangat penting. Apabila kontur rute tracking harus melewati lokasi berupa pegunungan atau perbukitan, maka perlu diperhatikan vegetasi lokasi dan garis kontur untuk memilih rute terbaik dan paling aman, serta perlengkapan keselamatan yang harus dibawa. Pembuatan penampang melintang sangat diperlukan untuk memperkirakan kondisi geografis yang akan ditempuh. Untuk membuat tampilan penampang melintang dapat dibuat manual dengan mengkalkulasikan jarak tempuh dengan garis kontur yang dilewati, namun dalam aplikasi SIG semuanya bisa dilakukan dengan komputer. Software yang dapat digunakan untuk membuat penampang melintang ini ialah Global Mapper. Global Mapper dapat menampilkan data geografis dalam bentuk 3D, dan dapat menampilkan penampang melintang dari rute yang dibuat. Tampilan geografis lokasi penelitian/situs dalam bentuk 3D juga terkadang dibutuhkan untuk melihat kondisi situs dalam bentuk gambaran lansekap yang lebih nyata.

Penggunaan Global Mapper cenderung lebih banyak digunakan untuk mendukung proses analisis. Dalam tahap ini, Global Mapper digunakan untuk analisis orientasi medan di lapangan pra penelitian. Namun dalam penyajian data informasi, ArcGis hampir memiliki semua fitur untuk SIG. Setelah persiapan orientasi medan dengan menggunakan analisis SIG, maka dapat disiapkan lembar peta cetak print untuk dibawa ke lapangan. ArcGis mampu membuat layout lembar peta sesuai dengan kebutuhan data yang ingin ditampilkan. Dengan adanya database SIG yang lengkap, maka memudahkan peneliti arkeologi untuk melakukan survey geografi situs/lokasi penelitian dengan cakupan wilayah yang luas dan waktu yang singkat. Dengan SIG, peneliti juga dapat membuat layout peta sendiri tak terbatas tanpa harus pembelian lembar cetak peta yang tentunya memerlukan dana yang tidak sedikit.

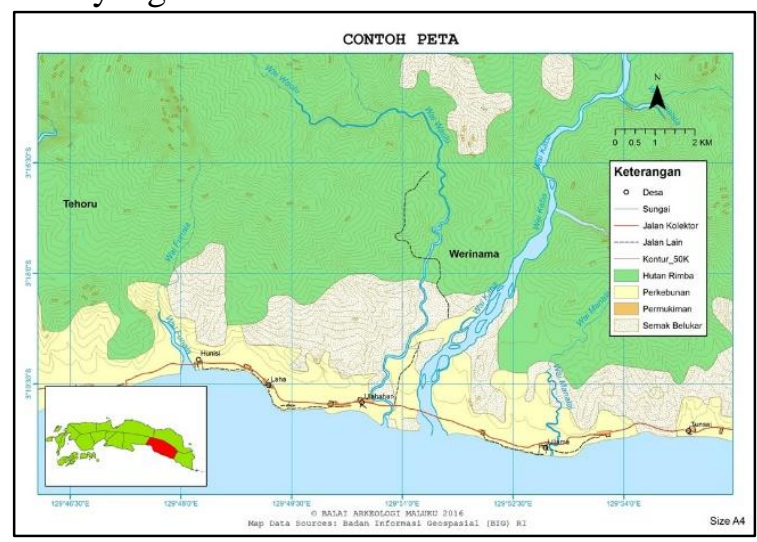

Gambar 5. Lembar Peta untuk dicetak

(Sumber: Peta dasar BIG diolah dalam ArcGis-

ArcMap, 2016)

Lembar peta yang telah dicetak dapat dibawa ke lokasi penelitian untuk membantu analisis di lapangan. Namun apabila lokasi penelitian berada dekat dengan permukiman yang tersedia listrik, maka dapat langsung saja membawa laptop yang memiliki software SIG untuk analisis. Saat analisis di lapangan, perlengkapan/peralatan standar untuk merekam data untuk SIG adalah Global Positioning System (GPS) dan lembar peta atau laptop yang memiliki software SIG. GPS tersedia dengan berbagai merk, namun GPS yang populer digunakan ialah GPS bermerk Garmin. Ragam GPS Garmin saat ini sudah cukup baik merekam data spasial dengan akurasi rata-rata ialah radius 5-2 meter, bahkan bisa sampai akurasi radius 1 meter. Namun perlu disadari, penggunaan GPS hanya untuk mendokumentasikan data spasial dalam cakupan wilayah yang luas, seperti situs, atau keletakkan fitur-fitur arkeologi. GPS 
sebaiknya tidak digunakan untuk mendokumentasikan data spasial dalam satu lokasi atau denah yang sempit karena akurasi GPS dalam mendokumentasikan data spasial yang tidak akurat $100 \%$. Dokumentasi spasial yang dimaksud adalah semua upaya pendataan dan identifikasi objek dipermukaan bumi yang menyertakan data koordinat lokasi sebagai referensi spasial (Sumarno, 2014: 3). Dalam proses pendokumentasian data spasial untuk denah suatu bangunan, situs, atau mungkin kotak ekskavasi yang ukuran luas keruangannya relatif kecil, maka sebaiknya menggunakan GPS Geodetik, atau perekaman menggunakan teodolit atau totalstation.

SIG sangat membantu dalam proses survey kawasan penelitian. Sebaran data spasial arkeologi dan lansekap situs yang sangat luas dapat direkam dan dianalisis lewat perangkat SIG. Eksplorasi atau survey lapangan di situs arkeologi untuk merekam lansekap yang sebelumnya memerlukan jangka waktu yang cukup lama dengan biaya dan tenaga yang tidak sedikit menjadi lebih efektif dengan database peta yang dapat diolah dalam SIG, sehingga hanya memerlukan waktu yang singkat dan sedikit biaya. Dengan adanya perekaman SIG, maka menghindari konflik lokasi serta penamaan situs dan kotak ekskavasi yang telah diekskavasi sebelumnya.

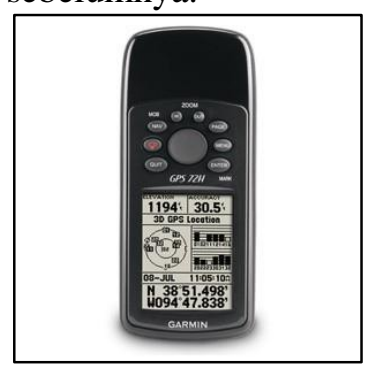

Gambar 6. Contoh GPS handheld Garmin 76CSx (Sumber: Balai Arkeologi Maluku, 2016)

Penggunaan GPS di dalam penelitian arkeologi sangat populer di kalangan peneliti saat ini. Jenis GPS yang digunakan ialah GPS handheld atau GPS genggam yang mudah dibawa. Pendokumentasian koordinat (akuisisi) suatu lokasi terbagi berdasarkan besaran luas keruangannya. Sampai saat ini tidak ada aturan resmi dalam akuisisi lokasi menggunakan GPS, akuisisi lokasi biasanya improvisasi peneliti di lapangan sesuai kebutuhan data lokasi yang akan direpresentasikan sesuai ukuran skala peta yang akan dibuatnya. Namun bila ditelaah berdasarkan UU no. 11 tahun 2010 tentang Cagar Budaya, jenis Cagar Budaya itu dapat disimpulkan antara lain Bangunan, Struktur, Situs, dan Kawasan. Representasi lokasi dalam peta ialah berupa titik, namun apabila format titik merepresentasikan suatu Situs atau Kawasan yang memiliki luas keruangan yang lebih besar maka format titik yang dipilih harus cukup merepresentasikan keletakkannya di lokasi tersebut. Apabila suatu Cagar Budaya yang sudah memiliki Datum Poin yang secara resmi ditetapkan, maka Datum Poin itulah yang direpresentasikan sebagai format titik lokasinya, namun apabila suatu Cagar Budaya belum memiliki Datum Poin yang ditetapkan, maka perlu kembali kepada analisis seorang peneliti untuk menetapkan titik akuisisinya.

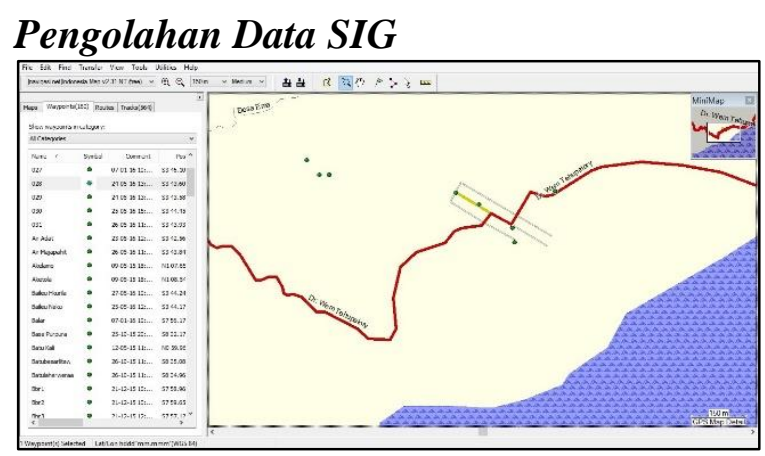

Gambar 7. Tampilan Mapsource

(Sumber: Balai Arkeologi Maluku, 2016)

Hasil akuisisi data lokasi di lapangan menggunakan GPS dieksport ke dalam mapsource. Mapsource ialah software bawaan dari GPS Garmin sebagai sarana untuk memindahkan data dari GPS ke dalam komputer. Data dari GPS diimport menggunakan mapsource dalam bentuk data *.gpx, atau *.gdb. Pada mapsource, peneliti dapat melakukan pengecekan kembali terhadap data spasial hasil akuisisi di lapangan. Pengecekan data dilakukan untuk melihat kebenaran lokasi data, menghindari konflik tumpang tindih data, dan menghapus data yang tidak relevan. Pengecekan ini penting dilakukan agar tidak ada kesalahan dalam penyusunan basis data.

Setelah peneliti selesai melakukan pengecekan data di dalam mapsource, artinya data spasial tersebut layak dimasukkan ke dalam basis data. Basis data spasial dibuat di dalam format Ms. Excel 97-2003 *.xls agar dapat dibaca oleh software-software SIG lainnya. Membangun basis data spasial terdiri dari 
membuat template berdasarkan data yang tersedia dan entry data ke dalam basis data yang telah disiapkan tersebut. Basis data yang dibangun berupa file geodatabase (ESRI ArcMap based). Geodatabase adalah basis data relasional yang memuat data spasial atau informasi geografis. Geodatabase terdiri dari klas fitur (spasial) dan tabel (non spasial). Data yang telah melalui proses digitasi dan pengolahan citra dimasukkan (upload) ke dalam personal geodatabase menggunakan ArcCatalog. Kelebihan dari personal geodatabase adalah kemampuannya untuk menyimpan beragam data (vektor, raster, survey data, tabel) dan menyimpan hubungan spasial (topologi, network) serta pengelolaan atribut (domain, joining ID, null value) (Riadi, Syafi'i, \& Widodo, 2011: 73). Struktur basis data berisi atribut-atribut informasi situs atau lokasi titik. Format struktur basis data spasial yang semakin lengkap maka semakin baik. Informasi dasar yang harus ada ialah, nama Situs atau lokasi dan koordinat decimal degree. Informasi dalam basis data spasial yang berguna antara lain, kode situs, datum poin, letak administrasi, koordinat UTM, koordinat degree minute second (DMS), elevasi, kategorisasi situs, periode penanggalan, riwayat penelitian, waktu pendataan, dan lain-lain. Namun pada kenyataannya tidak semua basis data yang dibuat oleh peneliti arkeologi berisi informasi selengkap itu.

\section{Bentuk Penyajian Data SIG}

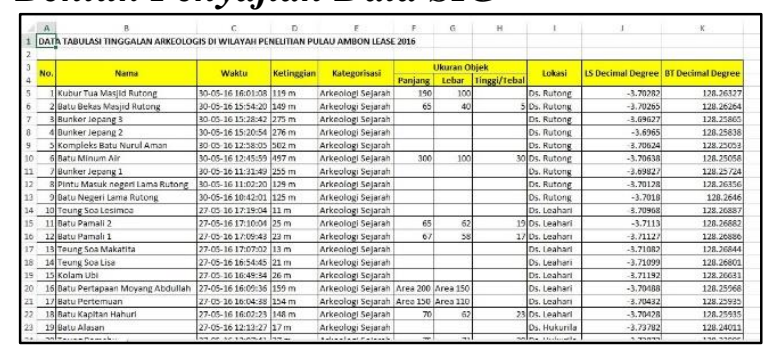

Gambar 8. Contoh Struktur Basis Data Spasial

(Sumber: Balai Arkeologi Maluku, 2016)

Basis data spasial dalam bentuk Ms. Excel yang telah dibuat merupakan informasi yang dapat dijadikan referensi untuk keperluan analisis peneliti. Basis data spasial juga merupakan arsip penelitian yang dapat dijadikan referensi untuk penelitian-penelitian mendatang. Basis data spasial yang sudah memuat informasi dasar yang diperlukan dapat ditampilkan dalam bentuk Peta menggunakan software-software geospasial, seperti ArcMap ArcGis. Software
ArcGis memiliki fitur yang lengkap dan sangat mumpuni dalam mengolah data spasial hingga menampilkannya dalam bentuk peta.

Setelah basis data ditampilkan dalam software ArcMap dalam bentuk sebaran titik, maka pada saat itulah peneliti melakukan analisis spasial. Analisis spasial dilakukan sesuai dengan kebutuhan berdasarkan tema penelitian yang dibuat oleh peneliti. Software ArcMap menyediakan fitur-fitur lengkap yang membantu peneliti dalam analisis data. Namun, kelengkapan fitur ArcMap harus ditunjang pula oleh ketersediaan atribut database peta dasarnya. Atribut-atribut tersebut menyangkut informasi geofisik peta, yaitu hipsografi, hidrografi, data lingkungan terbangun, data transportasi, toponimi, utilitas, dan vegetasi. Semakin banyak ketersediaan data geofisik tersebut, maka akan semakin membantu peneliti dalam menganalisis data geospasial karena banyaknya informasi spasial yang diperoleh.

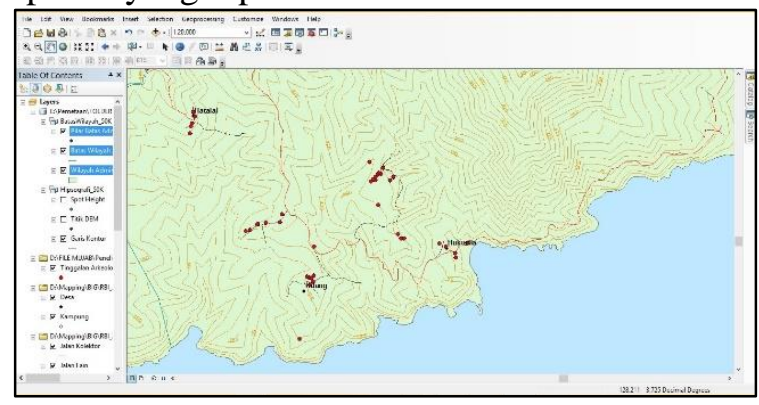

Gambar 9. Menampilkan Basis Data dalam ArcMap (Sumber: Balai Arkeologi Maluku, 2016)

Apabila atribut database peta dasar kurang mencukupi, maka dapat menambahkan referensi peta dasar lain yang diperoleh dari hasil scan lembar peta tematik yang sudah tersedia atau citra satelit. Citra satelit berasal dari teknologi penginderaan jauh yang menghasilkan berbagai jenis citra yang direkam dengan berbagai sensor (multisensor) yang mampu menghasilkan citra dengan multi resolusi. Citra Landsat merupakan salah satu citra yang sangat populer dan banyak digunakan di Indonesia sejak era berkembangnya citra satelit multisensor. Citra Landsat MSS, Landsat TM, sampai dengan Landsat ETM+ sudah banyak dimanfaatkan dalam berbagai bidang terapan di Indonesia karena memiliki resolusi spektral dan spasial yang sesuai disamping harganya yang cukup murah dan ketersediaannya yang memadai (Murti, 2012: 85). Software ArcMap memiliki fitur georeference yang dapat menyatukan 
beberapa data spasial seperti citra satelit, arsip peta tematik, atau peta denah situs yang pernah dibuat. Georeference ialah memasukkan koordinat bumi ke dalam peta. Proses ini dilakukan agar lembar citra satelit, peta tematik, peta denah situs, atau peta lainnya memiliki sifat-sifat proyeksi sesuai dengan kondisi lapangan. Tujuan dari georeference ini ialah sebagai referensi peta dasar alternatif, dan juga sebagai proses koreksi lembar data spasial dengan data spasial lainnya.

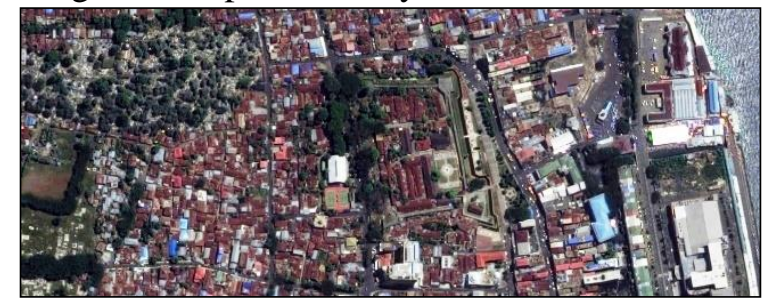

Gambar 10. Lembar Foto Citra Satelit di Sekitar Situs Fort Oranje, Ternate

(Sumber: https://www.google.co.id/maps/, 2016)

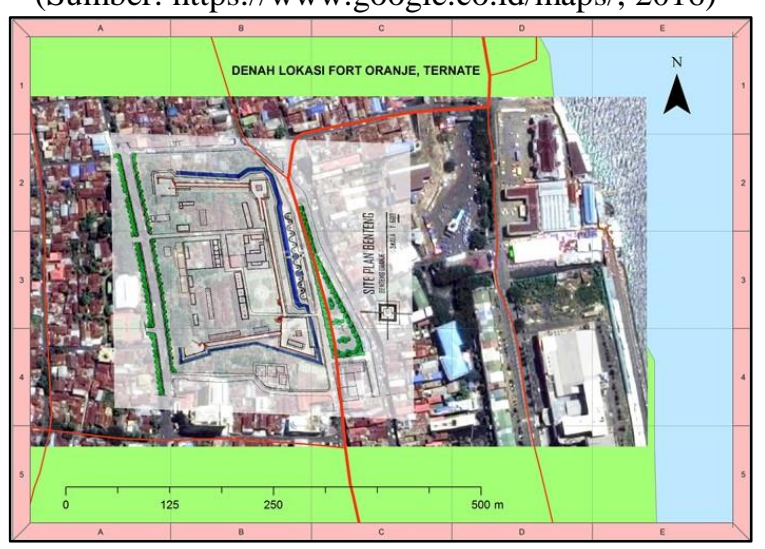

Gambar 11. Georeference Lembar Citra Satelit dengan Gambar Arsip Denah Situs

(Sumber: Balai Arkeologi Maluku, 2016)

Setelah proses analisis spasial selesai dilakukan dengan ArcMap, peneliti dapat menyajikannya dalam bentuk file lembar peta *.jpg yang siap untuk dicetak sebagai lampiran hasil penelitian. ArcGis dapat membantu dalam proses pembuatan layout peta yang sesuai dengan kebutuhan. Hasil layout peta disajikan dalam berbagai ekstensi file, seperti *.jpg, *.pdf, *.png, dan lainnya. Penyajian peta dibutuhkan sebagai lampiran pendukung hasil analisis penelitian maupun data referensi tulisan yang dapat dituangkan ke dalam bentuk laporan penelitian maupun naskah jurnal ilmiah.

Penyajian peta dapat disesuaikan berdasarkan kebutuhannya. Apabila peta berisi informasi spasial dalam lingkup keruangan yang relatif sempit atau kecil, maka dibuatlah peta berskala besar yaitu <1:10.000. Namun apabila peta berisi informasi spasial dalam lingkup keruangan yang relatif luas atau besar maka dibuatlah peta berskala kecil yaitu >1:10.000. Ukuran frame peta yang akan disajikan pun disesuaikan dengan kebutuhan detil data yang ingin ditampakkan. Semakin detail dan banyak data atau informasi yang ingin ditampakkan, maka semakin besar pula ukuran framenya, namun ukuran frame juga relatif tergantung kebutuhan peneliti dalam bentuk apa dan dimana melampirkannya. Dengan georeference dari beberapa informasi spasial berbeda maka peneliti dapat mengoreksi kesalahan-kesalahan dari informasi spasial, serta dapat melengkapi kekurangan-kekurangan dari data informasi spasial.

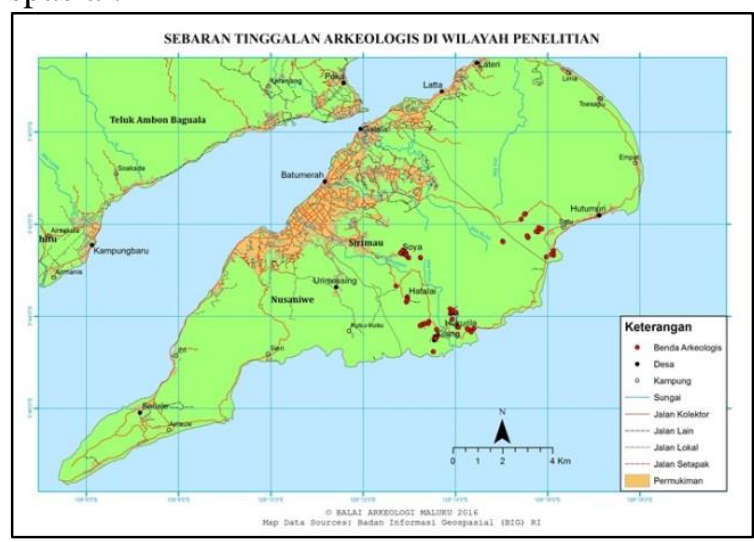

Gambar 12. Contoh Lampiran Peta pada Laporan Hasil Penelitian Arkeologi

(Sumber: Balai Arkeologi Maluku 2016)

\section{Peta Informasi Spasial Tematik}

Peta yang akan dilampirkan pada sebuah naskah jurnal atau laporan hasil penelitian arkeologi haruslah memuat informasi spasial yang mewakili atau menerjemahkan isi dari badan naskah. Fungsi peta ialah memuat informasi spasial geografis yang mampu memudahkan penerjemahan informasi spasial yang tidak cukup dituangkan dalam bentuk tulisan. Informasi-informasi spasial dapat dikemas ke dalam sebuah peta tematik, yaitu peta yang berisi informasi spasial tertentu yang lebih spesifik. Pada penelitian arkeologi, bentukbentuk sajian peta yang perlu dilampirkan sangat erat berkaitan dengan informasi tematik arkeologi. Kajian dan analisis arkeologi yang merupakan hasil penelitian di lapangan dan bertemakan kajian spasial pastilah memerlukan lampiran peta. Dewasa ini, kajian arkeologi 
lansekap cenderung lebih populer, sehingga peta yang memuat analisis arkeologi lansekap kerap disajikan dalam sebuah artikel jurnal maupun laporan hasil penelitian arkeologi. Dalam hal lain, ada pula peta arsip hasil penelitian yang biasanya tidak dilampirkan dalam publikasi ilmiah, namun digunakan dalam analisis arkeologi, yaitu peta delineasi situs, peta denah keruangan situs, peta grid ekskavasi arkeologi, dan lain-lain. Dengan menyajikan peta tematik, maka cukup mempertajam analisis arkeologi.

\section{Kendala-kendala Peneliti Arkeologi dalam Penerapan SIG}

Perangkat Sistem Informasi Geografis (SIG) penggunaannya sangat praktis dan sangat membantu kinerja Peneliti terutama yang membutuhkan aplikasi untuk membantu analisis spasial. Namun pada kenyataannya kendalakendala dalam penggunaan dan penerapan aplikasi SIG tetap ada. SIG itu terdiri atas rangkaian berbagai informasi data yang saling mendukung. Informasi-informasi tersebut dimulai dari proses input data informasi spasial di lapangan, pembuatan struktur basis data, ketersediaan database peta dasar, hingga proses penyajian peta jadi pada software aplikasi SIG. Saat ini peneliti arkeologi sangat mengenal penggunaan GPS. GPS tidak dapat lepas dari salah satu alat yang wajib dibawa ke lapangan saat melakukan penelitian, tujuannya yaitu akuisisi titik koordinat benda yang memiliki indikasi arkeologis di lapangan dan alat navigasi yang paling umum. Mengutip ungkapan Yuwono salah seorang ahli geoarkeologi, 'GPS sekarang ini bak kacang goreng, siapa pun menggunakan GPS dan menginput berbagai data spasial dengan GPS.' Artinya di kalangan peneliti arkeologi pun demikian, GPS merupakan alat andalan untuk mengakuisisi data koordinat. Karena hanya GPS yang tersedia, maka semua data diinput menggunakan GPS.

Seperti yang telah disebutkan bahwa GPS relevan digunakan untuk akuisisi data titik koordinat bangunan, lokasi dalam lingkup kewilayahan yang besar, karena akurasi GPS yang paling tinggi ialah satu meter, artinya resiko kesalahan koordinatnya ialah melenceng di dalam radius satu meter. Kalau mengakuisisi titik koordinat sebuah benda artefaktual yang berukuran $\mathrm{cm}$ atau sebuah temuan di dalam kotak ekskavasi menggunakan GPS maka dipastikan akan menghilangkan makna konteksnya, sehingga dapat mempengaruhi analisis peneliti. Perlu adanya pertimbangan dari seorang peneliti arkeologi dalam akuisisi titik koordinat dengan menggunakan GPS. Kekurangan GPS dalam mengakuisisi titik koordinat menjadi masalah ketika peneliti arkeologi melakukan pemetaan di dalam wilayah keuangan yang relatif sempit, seperti di lokasi kotak ekskavasi dan pemetaan situasi kotak ekskavasi berukuran $2 \times 2 \mathrm{~m}$ atau bahkan $1 \times 1 \mathrm{~m}$. Dalam melakukan pemetaan di lokasi seperti itu, jelas seharusnya GPS tidak bisa digunakan, perlu alat seperti total station atau GPS geodetik untuk memetakannya. Namun pada kenyataannya, peneliti arkeologi di lembaga riset arkeologi di Indonesia tidak memiliki dukungan peralatan dan perlengkapan selengkap itu. Sehingga proses pemetaan manual dengan improvisasi peneliti itu sendiri sangat dibutuhkan, kecuali memang sengaja mendatangkan tenaga ahli untuk situasi semacam itu.

Proses pencatatan basis data geospasial hasil penelitian arkeologi belum memiliki prosedur dan struktur yang seragam di seluruh lembaga riset arkeologi Indonesia. Bahkan kenyataannya pada saat ini peneliti arkeologi masih kesulitan dalam memperoleh basis data geospasial pada penelitian-penelitian yang pernah berlangsung akibat arsip basis data belum tersedia atau belum pernah dibuat. Kebanyakan peneliti hanya sekadar melampirkan data spasial dalam sebuah laporan penelitian, dan bukanlah dalam struktur basis data yang dapat dibaca oleh perangkat SIG. Arsip basis data geospasial tentunya sangat penting bagi peneliti arkeologi yang akan melakukan analisis spasial di masa datang. Arsip basis data geospasial juga turut memuat riwayat penelitian yang pernah berlangsung di suatu lokasi penelitian. Format struktur informasi basis data spasial arkeologi perlu disusun seragam untuk kebutuhan arsip penelitian di seluruh lembaga riset arkeologi di Indonesia.

Dalam melakukan analisis spasial menggunakan aplikasi SIG tentu membutuhkan basemap atau peta dasar dalam bentuk *.shp file atau *.gdb. Peta dasar tersebut memuat peta wilayah, batas administrasi, hipsografi, hidrografi, vegetasi, utilitas, lingkungan terbangun, dan lain-lain yang diperlukan untuk membantu proses analisis arkeologi. Namun kendala yang dihadapi oleh peneliti arkeologi 
ialah perolehan peta dasar tersebut. Sebelum kehadiran portal geospasial Badan Informasi Geografis (BIG) di laman http://tanahair.indonesia.go.id/ dan http://portal.ina-sdi.or.id/, untuk memperoleh peta dasar ialah dengan mengunduhnya di portal-portal asing yang tidak sedikit merupakan portal berbayar. Data peta dasar hasil unduhan dari portal asing sebenarnya seringkali dijumpai kesalahan-kesalahan pada beberapa model data, baik data poligon, titik, hingga toponimi, serta akurasi data spasial Indonesia yang disediakan oleh portal-portal asing tidak mampu memenuhi kebutuhan peneliti arkeologi yang meneliti hingga ke pelosok daerah di Indonesia. Kehadiran portal yang disediakan oleh BIG untuk publik secara gratis di sekitar tahun 2014 merupakan kabar baik, namun kenyataan hingga saat ini beberapa wilayah Indonesia yang bukan wilayah prioritas pembangunan masih belum memiliki akurasi data yang mumpuni. Namun harapan ke depan BIG dapat menyediakan seluruh data spasial wilayah Indonesia yang merata.

Kendala lain dalam penerapan perangkat SIG ialah sumber daya manusia (SDM) yang mampu mengaplikasikannya. Seperti yang sudah banyak diketahui, bahwa penerapan perangkat SIG bagi sebagian besar peneliti di Lembaga riset arkeologi masih dikenal sebagai 'barang' baru. Dalam satu Lembaga riset arkeologi, tenaga ahli yang bisa menerapkan aplikasi SIG bisa dihitung dengan jari, itu pun sebagian bukan merupakan tenaga peneliti. Kegiatan Sistem Pemetaan Arkeologi Nasional (SPAN) sejak 2010 cukup rutin dalam pengembangan aplikasi SIG di kalangan Balai Arkeologi, namun SDM yang dilibatkan hanya perwakilan tenaga teknis yang dianggap mampu menerapkan perangkat SIG di instansinya. Proses transfer ilmu pun kurang berjalan dengan baik karena kesibukan masing-masing peneliti dan tidak semua peneliti memandang perlu untuk menerapkan aplikasi SIG dalam penelitiannya. Kendala SDM ini memang kembali kepada keilmuan Sarjana arkeologi yang tidak dibekali pengetahuan tentang SIG di bangku kuliah. Sarjana arkeologi yang memiliki pengetahuan mengenai aplikasi SIG tentunya harus mengambil mata kuliah lintas Fakultas ke jurusan geografi yang memang tidak dijadikan sebagai mata kuliah wajib jurusan arkeologi. Kesadaran akan pentingnya pembekalan pengetahuan terhadap ilmu SIG di jurusan arkeologi baru diterapkan beberapa tahun terakhir ini. Departemen Arkeologi UGM dan UNHASsudah memasukkan kurikulum mengenai aplikasi SIG arkeologi sebagai mata kuliah wajib jurusan.

\section{Masa Depan SIG dalam Penelitian Arkeologi}

Sistem informasi geografis merupakan bagian dari kemajuan teknlogi informasi. Salah satu perkembangan di dalam bidang sistem informasi geografis adalah WebGIS. WebGIS adalah suatu sistem yang dapat terhubung ke dalam jaringan internet yang digunakan untuk mengumpulkan, menyimpan dan menampilkan data informasi bergeoreferensi atau data yang mengidentifikasikan lokasi objek tanpa adanya kebutuhan penggunaan software Sistem Informasi Geografis (Painho, Peixoto, Cabral, \& Sena, 2001 dalam Maharoesman, Suwardhi, \& Indrajaya, 2013: 36). Pada umumnya sistem informasi geografis konvensional membutuhkan software khusus untuk dapat mengaksesnya, sedangkan WebGIS memiliki akses data yang lebih mudah karena tidak membutuhkan software khusus tersebut. Sehingga WebGIS dapat diartikan sebagai GIS yang dapat diakses melalui jaringan internet (Maharoesman, Suwardhi, \& Indrajaya, 2013: 36).

Munculnya kebijakan Presiden mengenai One Map Policy atau Kebijakan Satu Peta di tahun 2015 cukup menambah perhatian Kemdikbud sebagai Lembaga tertinggi yang membawahi Lembaga riset Arkeologi terhadap perangkat SIG di instansi-instansi di bawahnya. Instansi di bawah Ditjen Kebudayaan dan Balitbang turut dilibatkan dalam percepatan Kebijakan Presiden ini. Data-data titik Cagar Budaya dan lokasi penelitian arkeologi menjadi bahan utama untuk diinput dalam mendukung percepatan Kebijakan Satu Peta. Berkat Kebijakan tersebut, cukup membuka mata para pemangku kebijakan terhadap perhatian akan pentingnya database geospasial yang terstruktur dalam satu jaringan di Lembaga riset arkeologi. Rencana dalam waktu dekat Kemdikbud akan meluncurkan WebGIS sebagai perangkat database geospasial yang berisi informasi terbuka mengenai data Cagar Budaya dan Lokasi penelitian arkeologi dengan Balai Arkeologi sebagai salah satu instansi penginput datanya. 


\section{KESIMPULAN}

Perangkat Sistem Informasi Geografis (SIG) jelas sangat membantu proses penelitian arkeologi baik di lapangan maupun saat proses analisis dan penyajian informasi terkait hasil penelitian. SIG menjadi pilihan bagi peneliti arkeologi dalam mengikuti perkembangan dunia riset yang serba digital, praktis, dan efektif. Gabungan dari SIG dan arkeologi telah menyempurnakan studi dari dimesi tingkah laku manusia di masa lalu, dikarenakan semua data arkeologi membawa aspek spasial. SIG bisa memproses dengan baik sejumlah besar volume data, terutama data geografis. Hal ini bisa menjadikan SIG sebagai perangkat yang mengurangi biaya penelitian secara efektif hingga mampu menampilkan data secara visual yang lebih komprehensif. Tidak hanya efektif dalam penyajian peta, dengan perangkat SIG, peneliti arkeologi dapat menggabungkan dan menganalisa tipe-tipe data yang berbeda dalam rangka menciptakan data baru. Diharapkan perangkat SIG di dunia penelitian arkeologi akan memegang peran yang cukup penting sehingga mampu meningkatkan kualitas hasil penelitian arkeologi Indonesia.

\section{Ucapan Terima Kasih}

Penulis mengucapkan terima kasih kepada Pusat Arkeologi Nasional yang telah secara rutin dan berkomitmen dalam pengembangan Sistem Pemetaan Arkeologi Nasional (SPAN). Terima kasih pula kepada Ditjen Kebudayaan Kemdikbud yang telah berusaha dalam mendukung percepatan kebijakan Satu Peta. Berkat itu, penulis memperoleh informasi dalam menyelesaikan riset kecil untuk tulisan ini. Semoga tulisan ini bermanfaat untuk menambah wawasan ilmu.

\section{$* * * * * *$}

\section{DAFTAR PUSTAKA}

Clarke, D. L. (1977). Spatial Archaeology. London: Academic Press.

Claxton, J. B. (1995). Future Enhancements to GIS: Implications for Archaeological Theory. In G. Lock \& Z. Stančič (Eds.), Archaeology and Geographical Information Systems (pp. 335348). London: Taylor and Francis.

Greene, K. (1995). Archaeology: An Introduction, The History, Principles and Methods of Modern Archaeology. Archaeology (3rd ed.). London:
Routledge.

Habib, S., \& Poniman, A. (2010). Pemanfaatan GIS untuk Rekontruksi Kawasan Strategis Nasional Trowulan. Globe, 12(2), 101-113.

Hakim, Y. F., Riqqi, A., \& Harto, A. B. (2014). Kontrol Kualitas dalam Alur Produksi Kartografi Peta di Badan Informasi Geospasial. Jurnal Ilmiah Geomatika, 20(1), 37-46.

Handoko, W. (2008). Kajian Arkeologi Lanskap dalam Konteks Penelitian Situs-situs Negeri Lama di Maluku: Sebuah Kerangka Metodologi. Kapata Arkeologi, 4(6), 84-105.

Hodder, I. (1999). The Archaeological Process: An Introduction. Oxford: Blackwell.

https://www.google.co.id/maps/. (2016). maps image.

Indonesia. Undang-Undang tentang Informasi Geospasial, Pub. L. No. 4 (2011). Indonesia.

Indonesia. Peraturan Presiden, Pub. L. No. 9 (2016). Indonesia.

Kresnawati, D. K., \& Atmadilaga, A. H. (2004). Panduan Membaca Peta Rupabumi Indonesia. Bogor: Bakosurtanal.

Maharoesman, Z. R., Suwardhi, D., \& Indrajaya, A. (2013). Pembangunan Sistem Informasi Geografis Berbasis Web untuk Kegiatan Ekskavasi Situs Warisan Budaya Indonesia (Studi Kasus: Komplek Candi Batujaya). Jurnal Konservasi Cagar Budaya Borobudur, 7(2), 3543.

Munajati, S. L., Anadra, R., \& Aprianto, A. (2010). Penentuan Sentra Peta di Wilayah Jakarta dengan Menggunakan Sistem Informasi Geografis. Globe, 12(1), 68-81.

Mundarjito. (1993). Pertimbangan Ekologi dalam Penempatan Situs Masa Hindu-Buda di Daerah Yogyakarta: Kajian Arkeologi-Ruang Skala Makro. Universitas Indonesia.

Murti, S. H. (2012). Pengaruh Resolusi Spasial pada Citra Penginderaan Jauh terhadap Ketelitian Pemetaan Penggunaan Lahan Pertanian di Kabupaten Wonosobo. Jurnal Ilmiah Geomatika, 18(1), 84-94.

Riadi, B., Syafi'i, A., \& Widodo, H. M. (2011). Pembangunan Sistem Informasi Spasial: Studi Kasus Kabupaten Pidiejaya, Provinsi Aceh. Globe, 13(1), 69-76.

Robertson, E. C., Seibert, J. D., Fernandez, D. C., \& Zender, M. U. (2006). Space and Spatial Analysis in Archaeology. Calgary: University of Calgary Press.

Schiffer, M. B. (1976). Behavioral Archaeology. New York: Academic Press.

Sharer, R. J., \& Ashmore, W. (1979). Fundamentals of Archaeology. California: Benjamin/Cummings Publishing Company, Inc.

Shaw, I., \& Jameson, R. (1999). A Dictionary of Archaeology. Oxford: Blackwell. 
Simanjuntak, T. (1999). Metode Penelitian Arkeologi. Jakarta: Pusat Penelitian Arkeologi Nasional.

Suantika, I. W. (2012). Pengelolaan Sumberdaya Arkeologi. Forum Arkeologi, 25(3), 185-205.

Sujana, U. (2015). Peran Sistem Informasi Geografis dalam Kajian Delineasi dan Zonasi Situs Liangan. Korakora, 2, 58-65.

Sumarno. (2014). Pemanfaatan WebGIS "Petakita" untuk Dokumentasi dan Sosialisasi Objek Arkeologi. Jurnal Itenas Rekayasa, 18(1), 1-8.

Wheatley, D., \& Gillings, M. (2002). Spatial Technology and Archaeology: The Archaeological Applications of GIS. London: Taylor \& Francis.

Yuwono, J. S. E. (2007). Kontribusi Aplikasi Sistem Informasi Geografis (SIG) dalam Berbagai Skala Kajian Arkeologi Lansekap. Berkala Arkeologi, XXVII(2), 107-136. 